cases of central colour scotoma in anterior uveitis, and that he concurs in my opinion as to the rôle of the intra-ocular inflammatory toxins.

The instrument is made by Theodore Hamblin, Ltd., Dispensing Opticians, 15, Wigmore Street, Cavendish Square, London. W.1.

\title{
REFERENCES
}

1. Holth, S.-Centralskotomsögeren. Forhandlinger i Det Norske medicinske Selskab. Pp. 113-114, 1905. Kristiania.

2. Holth, S.-Du diagnostic du scotome central pour les couleurs à l'aide de trois objets identiques simultanés. Ann. d'Ocul., T. CXL, pp. 169-175, 1908.

3. Holth, S. -Discussion sur Atrophie optique sympathique par le Dr. Péchin. Bull. et Mém. de la Société française d'Ophtal., T. XXVI, pp. 308-309, 1909.

4. Holth, S.-Das Kordenperimeter. Klin. Monatsbl. f. Augenheilk., Bd. LIII, pp. 197-201, Juli-August, 1914.

5. Engelking, E., und Eckstein, A.-Peripheriegleiche und invariable Perimeterobjekte zur Vereinfachung und Verbesserung der Farbenperimetrie. Fünf Farbenkartons : Rot, Gelb, Grün, Blau und Grau. Freiburg i Br. (Speyer \& Kärner), 1920.

6. Holth, S.-Meine Drei-Objekten-Probe für zentrales Farbenskotom auch bei Rotgrünblinden oder anderen Farbensinnabnormen. Klin. Monatsbl. f. Augenheilk., Bd. LXVII, pp. 166-171, 1921.

7. Holth, S.-Amblyopia centralis eines diabetischen Kettenrauchers, geheilt unter Insulinbehandlung trotz wiederaufgenommenen und fortgesetzten Nikotinismus. Acta Ophthal., Vol. V, pp. 195-198, 1927.

8. Clegg, J. Gray.-Central scotoma in anterior uveitis. Brit.Jl. of Ophthal., Vol. VI, pp 118-124, 1922.

9. Clegg, J. Gray.-Central scotoma in anterior uveitis. Trans. Ophthal. Soc. U.K., Vol. XLIV, pp. 86-89, London, 1924.

\section{MASSIVE RETINAL HAEMORRHAGE}

BY

\section{R. R. JAMES \\ LONDON}

THE publication of an abstract in Brit. Jl. of Ophthal., Vol. XI, p. 573, of a paper by A. Fuchs on "Rare Syphilitic Affections of the Eye," especially the third section entitled neuritis papulosa, has recalled to my mind two similar cases which have been under my care during the last eleven years. My cases differed from those described by Fuchs in being bilateral, whereas his are stated to have been unilateral; but, judging from the report, there is a large measure of similarity between them.

\section{Case I}

A man, aged 25 years, was referred to me from the V.D. department of St. George's Hospital in October, 1922, on account of defective vision of about five months' duration. He was wearing glasses of $-0.75 \mathrm{D}$. spherical strength. 
The eyes were free from inflammatory injection, precipitates were noted on the back of the right cornea, the pupils reacted to light, and the tension was normal. His vision was very defective, amounting to $<6 / 60$ in the right eye and $6 / 60$ in the left with correction. The pupils were dilated with homatropine; in the right eye the vitreous was found to be turbid with gross floating opacities, and no clear view of the fundus could be obtained; as far as could be seen no obvious lesion of the fundus was present. The left vitreous was much clearer and it was easy to see that a very peculiar picture was present. 'In this eye the disc was entirely
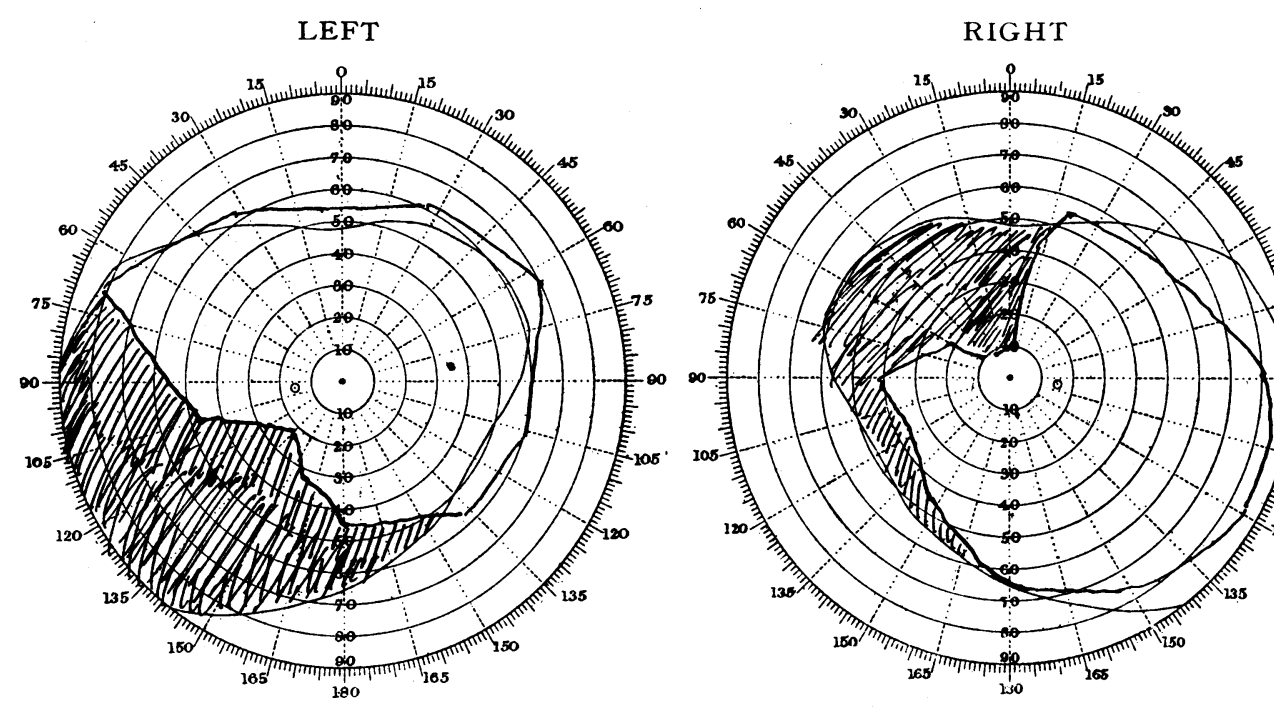

hidden by a large roughly quadrilateral mass of white exudate, at the upper edge of which were massive retinal haemorrhages. The mass came well forwards into the vitreous, and from under its . lower edge the main inferior branch of the retinal vein appeared and ran in a tortuous manner towards the periphery. It was dilated to about double the usual breadth and looked like a broad flat ribbon. No other gross lesion was to be seen in the fundus at this time. The fields showed marked semi-quadrantic contractions.

The question propounded to me was whether treatment by the newer arsenical preparations should be persisted in or not. I gave my opinion that the case should be treated on the old-fashioned lines with mercury and iodide. The man was accordingly admitted under the care of Dr. Fox, and was later transferred to the Eye wards under my care. On leaving the hospital he was kept under treatment in the V.D. department and I saw him at regular intervals. A steady improvement occurred in the left eye and the 
vision in the right began to improve also. Thus on November 11. 1922, R.V., 6/36; L.V., 6/18. I saw him on December, 30, 1922; he complained that the right eye had become very much worse a week earlier, and I noted that massive haemorrhages were present in the fundus. At this time the vision in the left eye was $6 / 12$ and the appearances shown in the drawing were beginning to be seen. The pictures were painted by Mr. Head in March, 1923. The left fundus showed a large area of choroidal disturbance upwards with a fold of organized retinitis proliferans running up to it along a branch of the superior retinal vein, which came forwards into the vitreous. In the right eye the disc was obscured by massive haemorrhage and the upper vessels were replaced by a cord-like structure which came forwards into the vitreous to a considerable extent; yet there was no retinal detachment of the ordinary type to be seen. The upper end of the cord-like structure bifurcated in a most odd manner. On June 9, 1923, his vision was noted to be $6 / 36$ in the right eye and part of $6 / 9$ in the left with his correction. At this date he informed me that he had obtained work at some distance from the hospital and that he would not be able to come and see me unless any deterioration in his vision took place. I am under the impression that he continued to attend the V.D. department for some months and then ceased attendance. I wrote to him in September, 1927, to ask him to attend for a further fundus drawing. He answered that he would come; that his left sight had kept quite good and that that of the right eye varied, occasionally it seemed a bit better and at other times worse. On September $1 \dot{j}$. 1927 , his vision was found to be $<6 / 60$ in the right eye and most of the letters of $6 / 6$ in the left. The condition of the left fundus was unchanged; that of the right is shown in the drawing by Hamblin, reproduced here; an extensive area of old choroidal change is to be seen below the disc, while a gross mass of organized exudate springs forwards from the outer border of the disc into the vitreous; one band appears to contain the main superior vessels and the fork is still evident; by moving the head a marked parallactic displacement is seen to occur between the two branches of the fork.

Unfortunately for the purpose of this record, the full notes of this case which I made at the time have been mislaid, and I cannot find them. I am therefore unable to give the measurements of the swellings in the vitreous, but my impression is that the cord-like prominence in the right eye was seen with $+8.0 \mathrm{D}$. sph.; and the exudate in the left with +5.0D. sph.

Full records of the general treatment of this case are preserved in the books of the V.D. department of the hospital. His first attendance was in June, 1922, and a history of infection in the previous February was noted. Prior to coming to London he had 


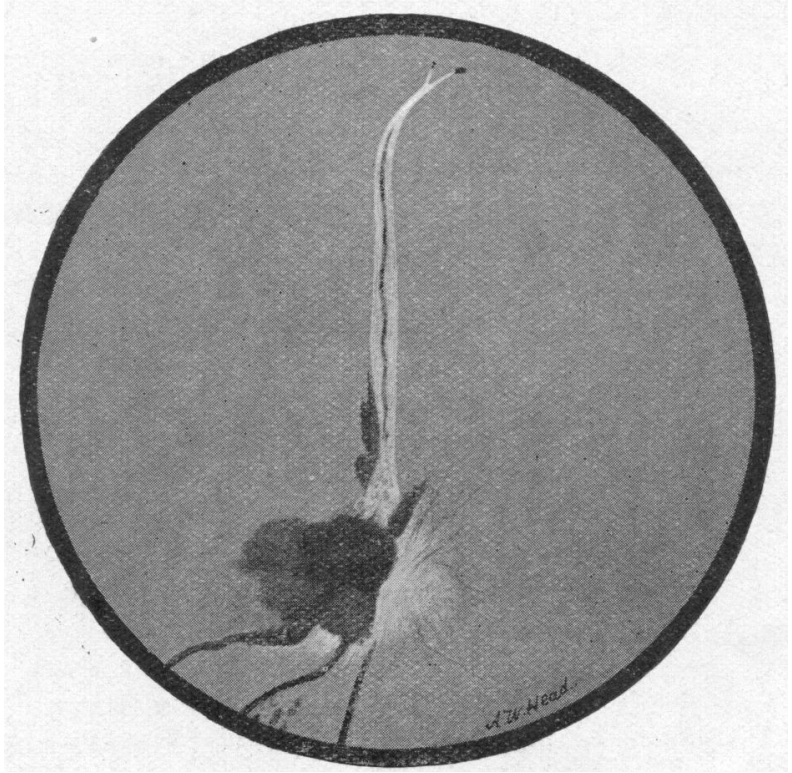

CaSe I. Right Eye. March, 1923.

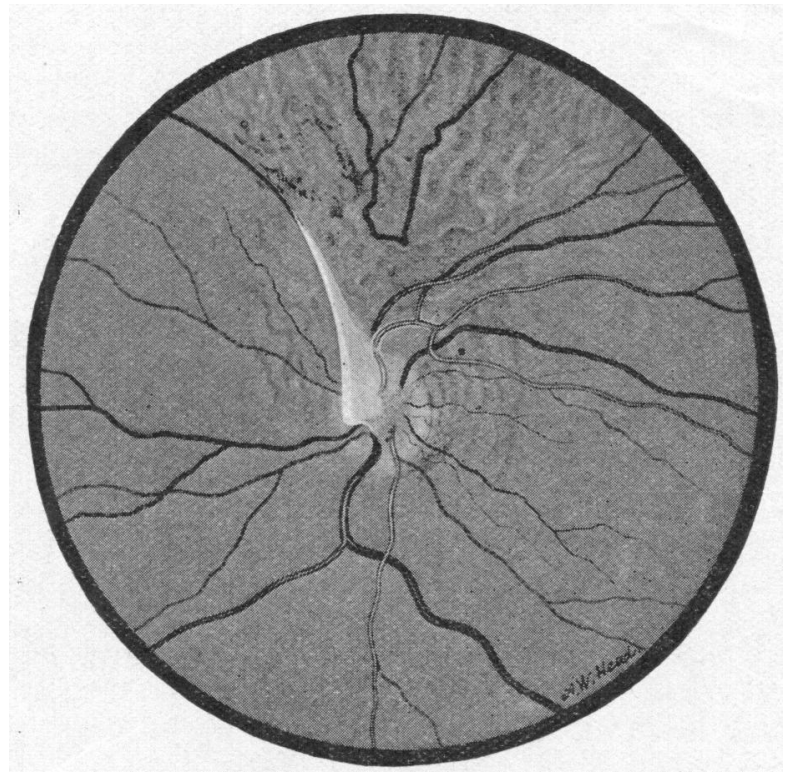

CASE I. Left Eye. March, 19:3. 
had treatment in Dublin, four injections of N.A.B. having been given. The Wassermann reaction on arrival at St. George's was positive, and he had secondary eruptions on the body. In September, 1922, the Wassermann reaction was negative ; arsenical preparations seem to have been given throughout and the Wassermann reaction was again positive in 1923 and 1924 ; by February,

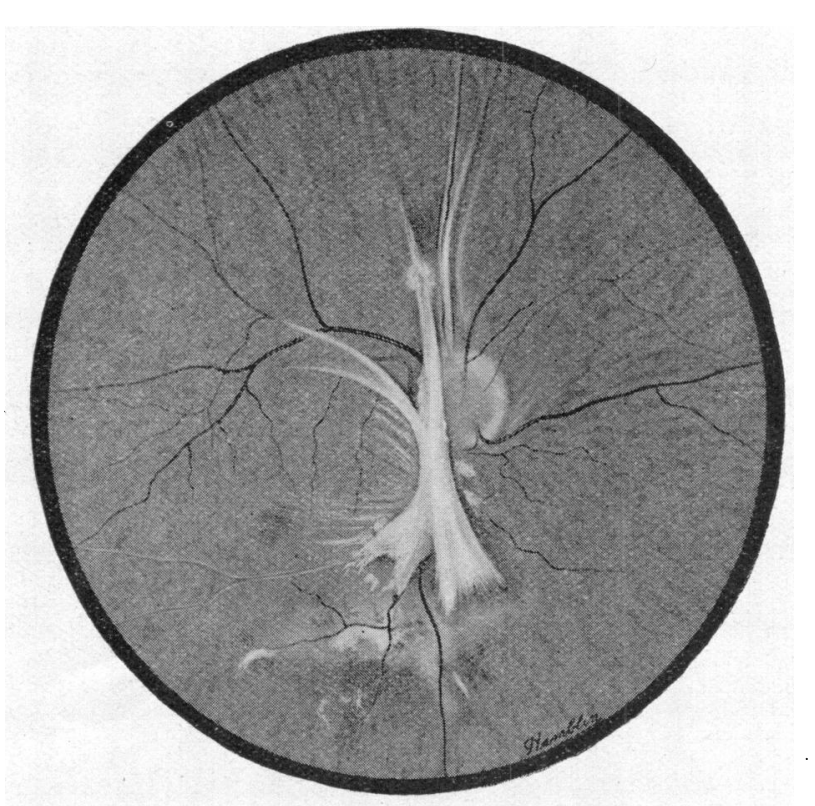

CASE I. Right Eye. September, 1927.

1925, he had already had four courses of arsenical preparations; in September of the same year the Wassermann reaction was negative and it has kept negative since that date. His last attendance in the V.D. department was January 31, 1927. I find from the notes that an injection of neosil $0.3 \mathrm{grm}$. was given on December 15,1922 , the right eye failed a week later so probably this was a coincidence and not directly due to the drug.

\section{Case II}

I do not think it quite correct to include this case under the syphilitic heading as the Wassermann reaction was done twice, each time with a negative result; but the clinical course was so similar to that of the first case that I think it justifiable to include a description of the case in this paper. 
Miss -, a poor-law infirmary nurse, was brought to see me in private by her sister in July, 1916. Her age was 22 years and there was a history of failure of vision in the right eye of a month's duration, together with headache. Both eyes had been inflamed nine years previously. The eyes were free from signs of active inflammation; the pupils acted to light, though a few old posterior synechiae were present in each pupillary area ; tension was normal. The teeth were suggestive of congenital syphilis, of the peg-top variety, without being notched. Vision in the right eye was $<6 / 60$, and in the left, part of $6 / 6$. The right pupil dilated into an irregular oval, a large web of opacity was seen in the vitreous and the reflex was very poor, no details of the fundus could be seen.

By the end of the month a fair reflex could be obtained from the periphery, projection of light was good, and the centre of the vitreous was still very opaque. On September 5 , I noted that details of the fundus could be seen in the outer periphery with +12.0D. sph.; some haemorrhage was present at this part of the retina, and as the projection in the nasal field was bad I queried the presence of a retinal detachment in the outer part of the fundus. She was admitted to St. George's Hospital on September 11. A careful clinical examination revealed nothing much amiss. The Wassermann reaction was negative. I am indebted to Dr. E. L. Hunt, Bacteriologist to St. George's Hospital for the following report on the quantitative von Pirquet test which was performed by him on September 18, 1916. Examined 46 hours after making the test, the 1 in 10 human O.T. showed positive results, i.e., redness and swelling, but no areola. The test was negative to undiluted P.T.O. (bovine tuberculosis). It was also negative to human old tuberculin in strengths of 1 in 100,1 in 500, 1 in 1,000, and 1 in 10,000. The control was also negative. The urine was normal. There were no signs of anything wrong in the chest or abdomen. The bloodcount was as follows: Red cells, 4,325,000. White, 14,000. Hb., 98 per cent. Colour index, 1.16. A differential count gave the following percentages : polymorphonuclear, 72 per cent.; lymphocytes, 18 per cent.; mononuclears, 8 per cent.; eosinophiles, 2 per cent.

In the first instance she was treated with hot-air baths, subconjunctival saline injections, and potassium iodide; but as no progress was made a course of tuberculin was started, for I thought it most probable that she was a case of recurrent haemorrhage of adolescents which is so often of a tuberculous nature. About September 14 a large buff-coloured elevation appeared in the lower periphery of the left eye accompanied by a star-shaped figure at the macula. Tuberculin treatment was begun on October 11, 1916, and was continued until June 28, 1917. In March, 1917, the 
right eye suddenly cleared up in a flash and she was discharged with R.V., $6 / 6$; L.V., part of $6 / 18$. At this time the right vitreous was almost free from floaters, the left vitreous was clear, the star figure was still present at the macula, but was less marked, and the buff-coloured elevation was less obvious. She was readmitted on April 16, 1917, with large retinal haemorrhages in the left eye; the condition of the fundus gradually improved and she went home on July 3. She was readmitted in October with a relapse in the left eye and was at last discharged with vision of 6/12 in the left eye on March 25, 1918. On October 11, 1918, R.V., $+1.0 \mathrm{D}$. sph., +0.5D. cyl. $70^{\circ}=6 / 5 ; \mathrm{L} . \mathrm{V} .,+1.0 \mathrm{D}$. sph. $=6 / 36$. The left vitreous was still very cloudy and some choroidal disturbance was noted in the periphery of the left eye. In March, 1924 , R.V., 6/9, +0.5D. cyl. $90^{\circ}, 6 / 6$; L.V., +0.75D. cyl. $180^{\circ}$ $6 / 9$ part; and J.1 binocularly at the ordinary reading distance. Gross floaters were present in each eye, fine white linear streaks were to be seen in the periphery of the right fundus and gross white plaques of organized exudation or haemorrhage were present in the periphery of the left, obscuring the vessels and projecting forwards into the vitreous. I have not seen her since but I saw her sister who first brought her to me last year and she told me that she was very well and had recently been married.

I ought to state that no other signs of congenital syphilis were noted in this case, there was no deafness and the corneae were clear. It should be noted that in the first case the retinitis proliferans is marked about the nerve-head, while in the second it is confined to the periphery.

These cases should be compared with the account of a case by Clapp, published in the Brit. Jl. of Ophthal., Vol. X, p. 435, of new-formed vessels in the vitreous of specific origin. Clapp expressed the opinion in his paper that the arsenical preparations are not those of choice in these cases, as intra-ocular haemorrhages were made worse thereby; in his case improvement seemed much more rapid under treatment with mercury and iodide. Although I have no proof that the arsenical preparations had any deleterious effect on the first of my two cases, I should still be inclined, if any similar case were to present itself to me, to recommend the older fashioned treatment. 